\title{
INDONESIAN LEARNING RELATIONSHIP WITH THE ENVIRONMENT
}

\author{
By : Desi Rahayu
}

\section{Rahayudesi1997@gmail.com}

Indonesian is a must in subjects at school. Indonesian lessons teach students about things around them, such as explanatory text lessons, news texts, language skills, and so on. The Indonesian lessons have something to do with the environment. For example, a news text that contains events happening around us based on facts. What we need to do in order to get the events that we will write about to become news is to pay attention to the environment around us. The incident must attract the attention of many people. If the information we want we already get. then we can write down these events based on news writing rules.

Other Indonesian language lessons related to the environment are descriptive text lessons. Descriptive text written by students about the environment will add to students' insight into the environment that the student wrote. Before the students describe the environment, of course the students must pay close attention to the environment that will be the object to be written, so that the explanation of the environment is in accordance with what is available.

Using the environment as a learning medium will make it easier for students to understand the text being studied. This is because students see the object being discussed in real terms, not just groping for the object being discussed. So that students are able to write it down in writing. Even so, teachers need to provide direction regarding language rules, so that students' writing can be even better.

The environment is not only related to Indonesian language learning materials, but the environment has an important role in students' understanding of the material being studied. For example, environmental conditions that are less conducive will make students lazy to learn, so that the material taught is not understood by students. Conversely, a conducive environment will increase students' enthusiasm for learning, so that the lessons taught will be easily understood by students.

Based on the questionnaire I distributed to UNP semester 5 students of 2020, the following data were obtained. The first statement, namely making the environment as a medium for learning text is something that needs to be done, $68.8 \%$ agreed, $28.1 \%$ strongly agreed, $3.1 \%$ disagreed, and $0 \%$ disagreed. The second statement, namely a conducive environment will increase students' comprehension power, $59.4 \%$ agreed, $40.6 \%$ strongly agreed, $0 \%$ disagreed, and $0 \%$ disagreed. For the third statement, making the environment as a medium in learning text will help students to understand the text more easily, get $59.4 \%$ agree, $31.3 \%$ strongly agree, $9.4 \%$ disagree, and $0 \%$ disagree. The fourth statement, namely using Indonesian in a school environment will increase students' fluency in Indonesian, 50\% strongly agree and $50 \%$ agree. The fifth statement, namely to improve students' understanding of the environment, the teacher can assign students to write descriptive texts about the environment around the school, $65.6 \%$ agree, $31.3 \%$ strongly agree, $3.1 \%$ disagree, and $0 \%$ disagreed.

In the sixth statement, namely environmental material as a lesson in Indonesian, 71.9\% agreed, $21.9 \%$ strongly agreed, $6.3 \%$ disagreed, and 0\% disagreed. The seventh statement, namely the environment has a big role for students to understand the material they are studying, $62.5 \%$ agree, $34.4 \%$ strongly agree, $3.1 \%$ disagree, and $0 \%$ disagree. The eighth question is to instill a sense of environmental awareness by applying environmental materials in Indonesian language learning. The results obtained were $65.6 \%$ agreed, $34.4 \%$ strongly 
agreed, $0 \%$ disagreed, and $0 \%$ disagreed. The ninth statement, namely environmental preservation efforts can be carried out by including stories about the environment in students' reading texts. In that statement $75 \%$ agreed, $25 \%$ strongly agreed, $0 \%$ disagreed, and $0 \%$ disagreed. For the tenth statement, namely the teacher has a major contribution to the awareness of students towards their environment. The results obtained were $62.5 \%$ agreed, $37.5 \%$ strongly agreed, $0 \%$ disagreed, and $0 \%$ disagreed.

Putri, Ramadhan, and Gani (2019) said "Language teaching has the aim to develop students' language skills". These language skills consist of listening, speaking, reading, and writing. The four skills influence each other. A person will not be able to speak if he cannot hear and someone will not be able to write if he is not skilled in reading.

Language is used as a tool to communicate with other people by paying attention to the language style used. The use of language style reflects the nature and character of a person. If he has polite language, then he will be seen by others as a person who has good character. Sumarsono (in Halawa, Gani, and Ramadahan, 2019) said that politeness in speaking is one aspect of language that can improve the emotional intelligence of the speakers. In line with that, Syahrul, (in Putri, Gani, and Ramadhan, 2019), states "politeness connects language with aspects of social structure life as well as codes of behavior and ethics".

The use of language in conversation in classroom learning is a social and cultural phenomenon that cannot be separated from the traditions of the speakers. The language used during learning should use polite language because the conversations of teachers and students in class are said to specify the values of politeness in speech acts (Ramadhan, 2008).

The school environment is one of the places that mostly involves speech acts as a process of interaction between students and educators or each other. Indonesian is a widely spoken language. One of the speech acts used in the classroom is directive speech acts. This speech act has great potential in conveying the function of politeness in language (Larassaty, Ramadhan, and Gani, 2016).

Literacy is defined as an activity to make students love reading activities and to build a foundation for reading and literacy is closely related to language skills. To make students love reading activities, teachers can provide material related to the environment that attracts students' attention and creates conducive environmental conditions so that students become enthusiastic in reading. This can increase students 'interest in reading and increase students' awareness of the environment. (Sukma, Indrawati, and Suriani, 2019).

Another language skill that students need to learn is writing skills. Morsy (in Amelia, Sukma, and Asma, 2015) said that writing skills are very much needed in this modern era and it can be said that people who are skilled in writing are characteristic of educated people. For that it is necessary to improve the skills of students in writing. The teacher can ask students to write down things in their environment.

Listening is one of the language skills that teachers and students must pay attention to in learning. To hone listening skills, students can take advantage of the technology that exists today. Students can listen to information via radio, television, or recordings when the teacher explains learning in class (Sukma, Mahyudin, Rahmatina, and Suriani, 2018.

Environmental education can help students understand their environment, be aware of environmental problems and think about human and environmental relationships (Lai, 2018 and Buldur and Ömeroglu, 2018, in Ramadhan, Sukma, and Indriyani, 2019). Environmental education can be done by providing materials about the environment and student reading materials containing about the environment. teachers can make the environment as a medium of learning. "The components of environmental education, such as attitudes, knowledge, and awareness, play an important role in student behavior throughout 
their life inside and outside the classroom" (B. Alagoz and O. Akman, in Sukma, Ramadhan, and Indriyani, 2020).

Based on the explanation above, it can be concluded that Indonesian language learning is related to the environment. The environment affects students' ability to understand learning. a conducive environment will make students comfortable and enthusiastic when learning, so that lessons can be accepted by students. However, on the other hand, an environment that is not conducive will hamper students' enthusiasm in learning and cause students not to pay attention to learning. 


\section{REFERENCE}

Amelia, Rizki, Elfia Sukma, dan Nur Asma. (2015). "Pembelajaran Menulis Laporan Percobaan dengan Pendekatan Saintifik di Sekolah Dasar”. Prosiding Seminar Nasioanl Jurusan PGSD, Vol 1 (1).

Halawa, Noibe, dan Erizal Gani, dan Ramadhan Syahrul. (2019). Kesantunan Berbahasa Indonesia dalam Tindak Tutur Melarang dan Mengkritik Pada Tujuh Etnis. Lingua, Vol 15(2).

Larassaty, Suci, Syahrul Ramadhan, dan Erizal Gani. (2016). "Representasi Tindak Tutur Direktif Bahasa Indonesia Kelas XI SMA Negeri 15 Padang”. Jurnal Pendidikan Bahasa dan Sastra Indonesia, Vol 5 (2).

Putri, Gusnita Roza, Syahrul Ramadhan, dan Erizal Gani. (2019). "Hubungan Kemampuan Berpikir Logis dengan Kemampuan Menulis Karangan Argumentasi Siswa Kelas X SMA Negeri 1 Rao Kabupatan Pasaman Barat”. Jurnal Pendidikan Bahasa dan Sastra Indonesia, Vol, 1 (1).

Putri, Silvia Wina, dan Erizal Gani, dan Syahrul Ramadhan. (2019). Penggunaan Prinsip Kesantunan Berbahasa dalam Talk Show Mata Najwa Edisi "100 Hari AniesSandi” memerintah Jakarta. Lingua, Vol 15 (1).

Ramadhan, Syahrul. (2008). "Representasi Kesantunan Tindak Tutur Berbahasa Indonesia dalam Pembelajaran di Kelas (Kajian Etnografi Komunikasi)”. Diksi, Vol 15 (2).

Ramadhan, Syahrul, Elfia Sukma, dan V Indriyani. (2019). Enviromental Education and Disaster Mitigation Through Language Learning. IOP Conference: Earth and Environmental Science, 314.

Sukma, Elfia, Ritawati Mahyudin, Rahmatina, dan Ari Suriani. (2018). Problems in Oral Language Teaching in Primary School. Advances in School Science, Education, and Humanities, Vol 301.

Sukma, Elfia, Tin Indrawati, dan Ari Suriani. (2019). Penggunaan Media Literasi Kelas Awal di Sekolah Dasar. Jurnal Inovasi Pendidikan dan Pembelajaran Sekolah Dasar, Vol 3 (2). 
Sukma, Elfia, Syahrul Ramadhan, dan V Indriyani. (2020). Integration of Inviromental Education in Elementary Schools. IOP Conf. Series: Journal of Physics: Conf. Series 1481). 


\section{LAMPIRAN}

Tabel 1

\begin{tabular}{|c|c|c|c|c|c|}
\hline No. & Statement & SS & $\mathbf{S}$ & KS & TS \\
\hline 1. & $\begin{array}{l}\text { Making the environment as a } \\
\text { medium for text lessons is } \\
\text { something that needs to be done. }\end{array}$ & $28,1 \%$ & $68,8 \%$ & $3,1 \%$ & $0 \%$ \\
\hline 2. & $\begin{array}{l}\text { A conducive environment will } \\
\text { increase the catch of students. }\end{array}$ & $40,6 \%$ & $59,4 \%$ & $0 \%$ & $0 \%$ \\
\hline 3. & $\begin{array}{l}\text { Making the environment as a } \\
\text { medium in learning text will help } \\
\text { students to more easily } \\
\text { understand the text. }\end{array}$ & $31,3 \%$ & $59,4 \%$ & $9,4 \%$ & $0 \%$ \\
\hline 4. & $\begin{array}{l}\text { Using Indonesian in a school } \\
\text { environment will increase } \\
\text { students' fluency in Indonesian. }\end{array}$ & $50 \%$ & $50 \%$ & $0 \%$ & $0 \%$ \\
\hline 5. & 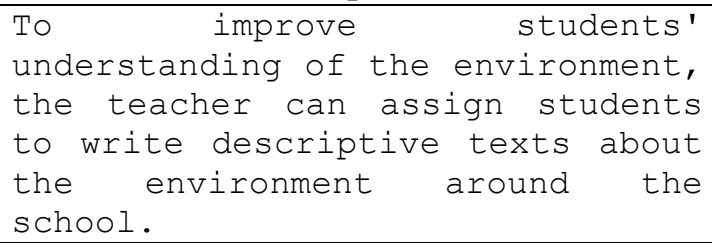 & $31,3 \%$ & $65,6 \%$ & $3,1 \%$ & $0 \%$ \\
\hline 6. & $\begin{array}{l}\text { Environmental material as one of } \\
\text { the Indonesian language lessons. }\end{array}$ & $21,9 \%$ & $71,9 \%$ & $6,3 \%$ & $0 \%$ \\
\hline 7. & $\begin{array}{l}\text { environment has a big share for } \\
\text { students to understand } \\
\text { material being studied. }\end{array}$ & $34,4 \%$ & $62,5 \%$ & $3,1 \%$ & $0 \%$ \\
\hline 8. & $\begin{array}{l}\text { Instilling a sense } \\
\text { environmental awareness can be } \\
\text { done by applying environmental } \\
\text { materials in Indonesian language } \\
\text { learning. }\end{array}$ & $34,4 \%$ & $65,6 \%$ & $0 \%$ & $0 \%$ \\
\hline 9. & $\begin{array}{l}\text { The ninth statement, namely } \\
\text { environmental preservation } \\
\text { efforts can be carried out by } \\
\text { including stories about the } \\
\text { environment in students' reading } \\
\text { texts. }\end{array}$ & $25 \%$ & $75 \%$ & $0 \%$ & $0 \%$ \\
\hline 10. & $\begin{array}{l}\text { For the tenth statement, namely } \\
\text { the teacher has a major } \\
\text { contribution to the awareness of } \\
\text { students towards } \\
\text { environment. }\end{array}$ & $37,5 \%$ & $62,5 \%$ & $0 \%$ & $0 \%$ \\
\hline
\end{tabular}

